\title{
IMPACT OF GLOBALISATION ON ECONOMIC GROWTH IN ROMANIA: AN EMPIRICAL ANALYSIS OF ITS ECONOMIC, SOCIAL AND POLITICAL DIMENSIONS
}

\author{
Neagu Olimpia, Ph.D \\ "Vasile Goldiș" Western University of Arad \\ olimpian2005@yahoo.com \\ Dima Stela, Ph.D \\ "Vasile Goldiș" Western University of Arad \\ dm_stela@yahoo.com
}

(Received January 2017; Accepted April 2017)

\begin{abstract}
The paper analyses the link between globalisation and economic growth in Romania for a time span of 24 years. Data from World Bank were used in an econometrical model in order to highlight the impact of globalisation, expressed by the KOF globalisation index and its components (economic, social and political globalisation indices) on economic growth rate. A statistical strong and positive link is found between GDP per capita dynamics and overall globalisation index as well as between GDP growth rate and economic and political globalisation, except the social dimension of globalisation which has a negative impact on economic growth in Romania for the time span 1990-2013.
\end{abstract}

Key words: open economy, economic growth, macroeconomic impacts of globalisation

JEL Codes: F41, F43, F62

\section{Introduction}

As a multidimensional concept, globalisation convers mainly, three areas: economic, social and political dimensions of human activity. In its content, globalisation means the integration of capital, investment and labour markets or its integration with world markets (WTO, 2008). Any country has to take advantage from its international connections, economic, trade, technology transfers or information flows in its economic growth process and benefit from the general process of markets integration and globalisation.

A critical problem of academics and scientists remained how to express the effect of globalisation on economic outcomes, taking into account its complex content. Dreher (2006, 2008) calculated a globalisation index including three subglobalisation indexes: economic, social and political. In the present paper this approach is used and the impact of these three dimensions on economic growth in Romania is analyzed. 
Neagu O., Dima S. (2017)

Impact of globalisation on economic growth in Romania: an empirical analysis of its economic, social and political dimensions

The aim of the paper is to highlight the impact of globalisation on the Romanian economy, by analyzing the effect of overall globalisation index values and of economic, social and political indexes on economic growth during 1990-2013.

The paper is organised as follows: after a short literature review on globalisation and economic growth, the methodology of the study is presented, the third section exposes the main findings and the final section is dedicated to conclusions.

\section{Globalisation and economic growth: a short literature review}

The impact of globalisation on economic output is a concern of economists and researchers from developed countries as well as from developing ones.

Many of them appeared after 2006, when Dreher launched firstly the KOF globalisation index, with its three subindexes (economic, social and political).

Dreher (2006) found out that globalisation affects economic growth in a positive way in his investigation of 123 countries from years 1970-2000.

The Pakistanese economy was explored by Afzal (2007) and Shaikh and Shah (2008) by using different methods and concluding that globalisation had an effect of development on economic growth in long term and influenced the Pakistan's macroeconomy performance in a positive way, leading to a fast economic growth.

The economic growth in well developed countries (OECD countries) is differently affected by globalisation, including its components: on the short term the influence is weak, whereas on the long run, there is a connection from general, economic and social globalization to economic growth (Chang and Lee, 2010).

Regarding the regional growth in the European Union (EU-27) countries, globalisation affected it in a positive way according to Polasek and Sellner (2011).

As the globalisation grows in Malaysia, Thailand, India and Philippines, the economic growth rates are higher too in these countries (Rao et al., 2011).

For the case of Romanian economy, there are valuable the conclusions of Mutascu and Fleischer (2011) stating that on middle and log run, globalisation would maximize the economic growth. But during 1992-2011 globalisation in Romania conducted to a higher income inequality (Neagu, 2014), .although a strong positive and statistical validated link is found between globalisation and FDI, between trade openness and FDI, and between FDI and globalisation (Dima, 2016) and the impact of globalisation on Romanian SMEs could be treated as an opportunity or as a threat (Zamfir, 2015).

Between the years 1995-2008, in the American economy globalisation increases and provokes the economic growth (Leitão, 2012).

Globalisation could be seen as an engine for economic growth (Ioviţu et al., 2015) and there is a mutual causality connection between globalisation and economic 
Neagu O., Dima S. (2017)

Impact of globalisation on economic growth in Romania: an empirical analysis of its economic, social and political dimensions

growth in developing countries (Morita et al., 2015) such as: India (Ray, 2012), Nigeria and Bangladesh (Umaru et al., 2013; Meraj, 2013) India and China (2015).

In ASEAN countries, globalisation affects positively economic growth, but social and political globalisation in a negative way (Ying, 2014).

In a panel data analysis including 74 developing countries, Kilic (2015) found that economic growth is positively affected by economic and political globalisation whereas social globalisation affects it negatively. Moreover, he has revealed two types of causality relationships: (1) one way causality relationship between economic growth and globalisation and (2) two way causality relationship between political and social globalisation and economic growth.

In the last years, it raised the attention given the political dimension of globalisation, due to changes in the political arena, shifts in geopolitical arrangements, popular mobilisation and contestation over the direction of globalisation (Smith et al., 2017).

\section{Data and methodology}

In the paper, World Bank data series of GDP per capita (2005 constant USD) and GDP growth rate (\%) for the time span of 1990-2013 were used.

From the KOF globalisation index data base were extracted data series for Romania regarding: overall index of globalisation, economic, social and political indexes.

The overal globalisation index has three components: economic globalisation index (36\%), social globalisation index (37\%) and political globalisation index (27\%). Economic globalisation index includes two sub-indexes: flows (50\%) (trade, foreign direct investment, portofolio investments, income payment to foreign nationals) and restrictions (50\%) (hidden import barriers, mean tarrif rate, curent revenue percentage of taxes on international trade and capital account restrictions). Social globalisation index inclues three sub-indexes: personal contact (33\%) (telefon traffic, transfers, international toursim, the foreign population according to the total population and international letters per capita), information flows (35\%) (internet usage per 1000 people, television per 1000 people and trade in newspapers) and cultural proximity (32\%) (number of McDonald's restaurants per capita, numebr of IKEA per capita and trade in books). Political globalisation index is calculated with four sub-indexes: number of embassies in country, membership in international organisations, participation in United Nation (UN) Security Council mission and international treaties.

We assume that economic output is a function of globalisation index, other factors remaining constant:

Studia Universitatis "Vasile Goldis" Arad. Economics Series Vol 27 Issue 1/2017

ISSN: 1584-2339; (online) ISSN: $2285-3065$ 
Neagu O., Dima S. (2017)

Impact of globalisation on economic growth in Romania: an empirical analysis of its economic, social and political dimensions

$$
G D P_{p c}=f(G I)
$$

where: $G D P_{p c}$ is GDP per capita (in 2005 constant USD) and GI is the overal globalisation index.

We transpose the relation (1) in a linear regression equation in order to estimate the impact of overall globalisation index (GI) on economic output $\left(G D P_{p c}\right)$ :

$$
G D P_{p c}=C+\alpha \cdot G I+\varepsilon
$$

where: $\mathrm{C}$ is a constant (intercept), $\alpha$ is a parameter and $\varepsilon$ is the error.

We intend to test the effects of all globalisation components en economic growth in the following regression equation:

$$
G D P_{\text {rate }}=C+\beta_{1} \cdot E G I+\beta_{2} \cdot S G I+\beta_{3} \cdot P G I+\varepsilon
$$

where: $G D P_{\text {rate }}$ is the annual growth rate of GDP, $\beta_{1}, \beta_{2}, \beta_{3}$ are regression parameters to be estimated, EGI is the economic globalisation index, $S G I$ is the social globalisation index, $P G I$ is the political globalisation index and $\varepsilon$ is the error. Data were processed by Eviews 8.0 software.

\section{Main findings}

The globalisation index evolved in Romania in the period of 1990-2013 in a strong connection with GDP per capita (Figure 1). 
Neagu O., Dima S. (2017)

Impact of globalisation on economic growth in Romania: an empirical analysis of its economic, social and political dimensions

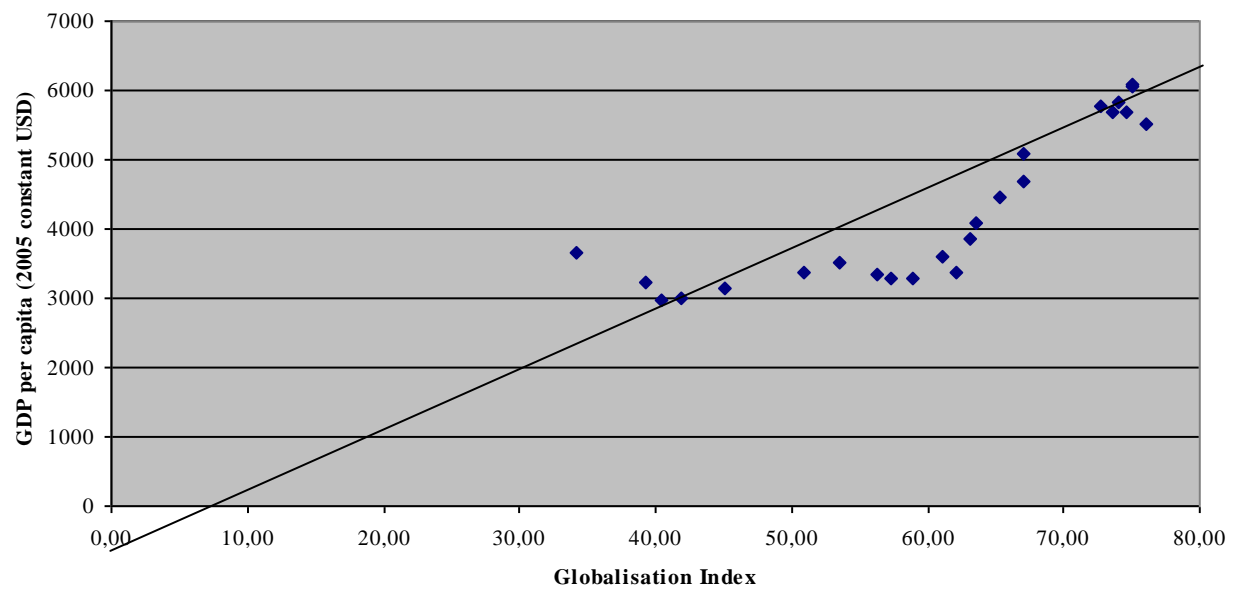

Figure 1. The dependency between economic output and globalisation in Romania (1990-2013)

Source: author's own computation based on World Bank data and KOF globalisation data

The results of estimation of equation (2) are displayed in the Table 1.

\section{Table 1-Results of estimation equation 2}

Dependent Variable: GDPPC

Method: Least Squares

Date: 06/25/16 Time: 18:24

Sample: 19902013

Included observations: 24

\begin{tabular}{lrlrr}
\hline \hline \multicolumn{1}{c}{ Variable } & Coefficient & \multicolumn{1}{c}{ Std. Error } & t-Statistic & Prob. \\
\hline \multicolumn{1}{c}{ C } & -238.6371 & 614.2310 & -0.388514 & 0.7014 \\
\multicolumn{1}{c}{ GI } & 74.74457 & 9.964158 & 7.501343 & 0.0000 \\
\hline \hline R-squared & 0.718922 & Mean dependent var & 4272.224 \\
Adjusted R-squared & 0.706146 & S.D. dependent var & 1131.274 \\
S.E. of regression & 613.2443 & Akaike info criterion & 15.75506 \\
Sum squared resid & 8273509. & Schwarz criterion & 15.85323 \\
Log likelihood & -187.0607 & Hannan-Quinn criter. & 15.78110 \\
F-statistic & 56.27015 & Durbin-Watson stat & 0.252079 \\
Prob(F-statistic) & 0.000000 & & \\
\hline \hline
\end{tabular}

DE GRUYTER OPEN
Studia Universitatis "Vasile Goldis" Arad. Economics Series Vol 27 Issue 1/2017 ISSN: 1584-2339; (online) ISSN: 2285 - 3065

Web: publicatii.uvvg.ro/index.php/studiaeconomia.Pages $29-40$ 
Neagu O., Dima S. (2017)

Impact of globalisation on economic growth in Romania: an empirical analysis of its economic, social and political dimensions

Source: author's own computation using Eviews 8.0 software

The estimated equation 2 is the following:

$G D P_{p c}=-238.6372+74.74457 \cdot G I$

For 5\% significance threshold, the regression equation is validated due to the fact that Prob (F-statistic) is $0.000<0.05$ and F-statistic is $56.27>F_{0,05 ; 1,24}=4.26$.

The determination coefficient (R-squared) is 0.718922 meaning that $71.82 \%$ of the variation of GDP per capita can be explained by the variation of globalisation index (GI). The value of adjusted R-squared (0.706146) is close to the R-squared meaning that our sample is relevant for an accurate representation of the reality.

The parameter $\alpha$ has the value of 74.74457 showing that for an increase with one unit of GI GDP per capita will increase with 74.74457 units, if other factors are remaining constant.

In order to test the heteroskedasticity of errors we used the White test (Table 2).

Table 2-Heteroskedasticity test for equation 2

Heteroskedasticity Test: White

\begin{tabular}{llll}
\hline \hline F-statistic & 1.097165 & Prob. F(2,21) & 0.3522 \\
Obs*R-squared & 2.270552 & Prob. Chi-Square(2) & 0.3213 \\
Scaled explained SS & 1.359189 & Prob. Chi-Square(2) & 0.5068 \\
\hline
\end{tabular}

Source: author's own computation using Eviews 8.0 software

Due to the fact that Obs R-squared has the value of $2.270552<\chi_{0,05 ; 2}^{2}=5.99$, the null hypothesis is accepted, errors are homoskedastic, meaning that the variation of dependent variable (GDP per capita) is remaining the same for any level of independent variable (GI).

We intend to check the causality sense of the relationship between GDP per capita and globalisation index. We used the Granger causality test from Eviews. The result displayed in the Table 3 show us that the value of F-statistic (9.20395) is higher than $F_{0,05 ; 1,22}=4.3$, meaning that the null hypothesis is rejected and GI does cause GDP per capita. 
Neagu O., Dima S. (2017)

Impact of globalisation on economic growth in Romania: an empirical analysis of its economic, social and political dimensions

\section{Table 3-Causality test}

Pairwise Granger Causality Tests

Date: 06/25/16 Time: 20:09

Sample: 19902013

Lags: 1

\begin{tabular}{|c|c|c|c|}
\hline Null Hypothesis: & Obs & F-Statistic & Prob. \\
\hline GI does not Granger Cause GDPPC & 23 & 9.20395 & 0.0066 \\
\hline GDPPC does not Granger Cause GI & & 0.38563 & 0.5416 \\
\hline
\end{tabular}

Source: author's own computation using Eviews 8.0 software

We intend further to explore how the growth rate is affected by the three components of globalisation index: economic, social and political. The results of estimation of equation (3) are exposed in the Table 4.

\section{Table 4- Estimation results of equation 3}

Dependent Variable: GDPR

Method: Least Squares

Date: 06/25/16 Time: 20:44

Sample: 19902013

Included observations: 24

\begin{tabular}{lrlrl}
\hline \hline \multicolumn{1}{c}{ Variable } & Coefficient & \multicolumn{1}{c}{ Std. Error } & t-Statistic & Prob. \\
\hline \hline \multicolumn{1}{c}{ C } & -48.33516 & 9.919094 & -4.872941 & 0.0001 \\
\multicolumn{1}{c}{ EGI } & 0.636056 & 0.247003 & 2.575093 & 0.0181 \\
\multicolumn{1}{c}{ PGI } & -0.598024 & 0.185720 & -3.220025 & 0.0043 \\
& 0.547607 & 0.135323 & 4.046676 & 0.0006 \\
\hline \hline R-squared & 0.573061 & Mean dependent var & 2.416869 \\
Adjusted R-squared & 0.509020 & S.D. dependent var & 5.740691 \\
S.E. of regression & 4.022500 & Akaike info criterion & 5.772696 \\
Sum squared resid & 323.6101 & Schwarz criterion & 5.969038 \\
Log likelihood & -65.27235 & Hannan-Quinn criter. & 5.824786 \\
F-statistic & 8.948365 & Durbin-Watson stat & 1.709481 \\
Prob(F-statistic) & 0.000582 & & \\
\hline \hline
\end{tabular}

Source: author's own computation using Eviews 8.0 software 
The estimated regression equation 3 has the following form:

$$
G D P_{\text {rate }}=-48.33516+0.636056 \cdot E G I-0.598024 \cdot S G I+0.547607 \cdot P G I
$$

The model is statistically validated for a significance threshold of $5 \%$, due to the fact that Prob (F-statistic) is $0.000582<0.005$ and F-statistic $(8.948365)>F_{0,05 ; 3,20}=$ 3.10. The economic dimension of globalisation expressed by EGI has a positive validated impact on GDP rate: the coefficient of EGI is 0.660563 for a Prob of $0.0181(<0.05)$ and a standard error of 2.57 . The social globalization (SGI) has a negative validated influence on GDP rate, its coefficient is -0.598024 for a Prob of 0.0043 and a standard error of -3.22 . The political index of globalization PGI has a positive impact on GDP rate: its coefficient is 0.547607 for a Prob of 0.0006 and a standard error of 4.04 .

A possible explanation of this negative influence of social dimension of globalization on GDP rate could be that variables related to international connections such us: international tourism, foreign population, internet users, television, trade in newspaper, number McDonald's restaurants and of IKEA or trade in books were evolving in an inverse sense as the GDP rate. It is a paradox that a country such Romania, placed in Central-Eastern part of Europe open to both, Western and Eastern, economic and information flows couldn't benefit from this position. It is suggesting for more appropriate public policies to take advantage from this location for its integration in the global society.

The impact of political dimension of globalization on economic growth is related to the Romania's international diplomatic involvement: membership in international organizations and treaties, participation in United (UN) Security Council missions and number of embassies. The coefficient of this variable is close to the economic dimension of globalization, showing a similar effect on the GDP rate.

We tested the heteroskedasticity of errors by using the White test (Table 5).

The value of Obs*R-squared (8.134322) is $<\chi_{0,05 ; 4}^{2}=9.49$, meaning that the model is homoscedastic for a significance level of $5 \%$, the variation of dependent variable being constant for any level of independent variables.

Table 5-Heteroskedasticity test for equation 3

Heteroskedasticity Test: White

\begin{tabular}{llll}
\hline F-statistic & 0.797532 & Prob. $\mathrm{F}(9,14)$ & 0.6250
\end{tabular}


Neagu O., Dima S. (2017)

Impact of globalisation on economic growth in Romania: an empirical analysis of its economic, social and political dimensions

\begin{tabular}{lllr} 
Obs*R-squared & 8.134322 & Prob. Chi-Square(9) & 0.5207 \\
Scaled explained SS & 7.145797 & Prob. Chi-Square(9) & 0.6219 \\
\hline \hline
\end{tabular}

Source: author's own computation using Eviews 8.0 software

Regarding the errors autocorrelation, the Durbin Watson statistic (1.709481) is between $\mathrm{d}_{1}=0.93$ and $\mathrm{d}_{2}=1.9$ meaning that this test in not relevant. Therefore, we used the Breusch-Godfrey test (Table 6):

\section{Table 6 -Errors autocorrelation detection}

Breusch-Godfrey Serial Correlation LM Test:

\begin{tabular}{llll}
\hline \hline F-statistic & 0.402964 & Prob. F(1,19) & 0.5331 \\
Obs*R-squared & 0.498435 & Prob. Chi-Square(1) & 0.4802 \\
\hline \hline
\end{tabular}

Source: author's own computation using Eviews 8.0 software

The value of Obs*R-squared $(0.498435)<\chi_{0,05 ; 4}^{2}=9.49$, meaning that the null hypothesis is accepted and the errors are independent.

We further tested the multicolinearity of explanatory variables with the Principal Components Analysis (Table 7).

\section{Table 7- Detection of multicolinearity of explanatory variables}

Principal Components Analysis

Date: 06/25/16 Time: 22:03

Sample: 19902013

Included observations: 24

Computed using: Ordinary correlations

Extracting 3 of 3 possible components

\begin{tabular}{cccccr}
\hline \hline \multicolumn{2}{c}{ Eigenvalues: $($ Sum $=3$, Average $=1)$} & & & & \\
Number & Value & Difference & Proportion & $\begin{array}{r}\text { Cumulative } \\
\text { Value }\end{array}$ & $\begin{array}{r}\text { Cumulative } \\
\text { Proportion }\end{array}$ \\
\hline \hline \multirow{2}{*}{1} & 2.683411 & 2.406007 & 0.8945 & 2.683411 & 0.8945 \\
2 & 0.277404 & 0.238219 & 0.0925 & 2.960815 & 0.9869 \\
3 & 0.039185 & --- & 0.0131 & 3.000000 & 1.0000 \\
\hline \hline
\end{tabular}

Eigenvectors (loadings):

$\begin{array}{llll}\text { Variable } & \text { PC } 1 & \text { PC } 2 & \text { PC } 3\end{array}$


Neagu O., Dima S. (2017)

Impact of globalisation on economic growth in Romania: an empirical analysis of its economic, social and political dimensions

\begin{tabular}{crrr}
\hline \hline EGI & 0.587992 & -0.442357 & 0.677189 \\
PGI & 0.548444 & 0.833402 & 0.068195 \\
SGI & 0.594538 & -0.331302 & -0.732642 \\
\hline \hline Ordinary correlations: & & & \\
& EGI & PGI & SGI \\
\hline EGI & 1.000000 & & \\
PGI & 0.764889 & 1.000000 & \\
SGI & 0.959289 & 0.796430 & 1.000000 \\
\hline \hline
\end{tabular}

Source: author's own computation using Eviews 8.0 software

All partial correlation coefficients: between EGI and PGI (0.764889), between EGI and SGI (0.959289) and between SGI and PGI (0.796430) are higher than the Rsquared 0.573061 (Table 4) meaning that all explanatory variables are multicolinear.

\section{Conclusions}

The aim of the paper was to highlight the impact of globalisation on economic growth in Romania. Overall, in the period examined, a strong positive statistical validated influence of globalisation on economic growth is found for a statistical threshold of 0.05 and we found a significant causality running from globalisation index to GDP per capita. This result shows that if Romania tends to maximize its economic growth, it has to globalize more.

The estimated econometric model is stable due to the homoskcedasticity of errors, but as limits of it, we mention the multicolinearity of the explanatory variables of globalisation.

Regarding the components of globalisation, the economic side had the most powerful positive influence on GDP per capita, the social dimension influenced it negatively and the political side of Romanian globalisation process has a positive impact on GDP per capita.

According to our findings, that information exchanges, technology transfers, convergence in cultural activity or people interaction and other social elements have to be stimulated in order to contribute to the integration of Romania in the global economy.

Pointing out the link between national development and globalisation, the paper is relevant for the Romanian policy makers when they design economic policies aiming to stimulate the economic growth. 
Neagu O., Dima S. (2017)

Impact of globalisation on economic growth in Romania: an empirical analysis of its economic, social and political dimensions

Our findings support previous literature on contribution of globalisation to economic growth. For example, in opinion of Dreher (2006) trade liberalization and export orientation can be a key driver of economic growth.

Further directions of research are needed to explain the impact of each component of globalisation index (economic, social and political) on GDP rate through their own structure (i.e. foreign direct investment, trade, people social interaction, culture convergence, international participation etc.). Another idea to extend the present study is to explore the effect of globalisation on economic growth within some groups of countries (developing or developed) with similar evolution, by using panel data techniques, in order to extract valuable conclusions for governments and policy makers.

\section{References}

1. Afzal, M. (2007). The impact of globalization on Economic Growth of Pakistan. The Pakistan Development Review, 46(4), pp.723-734.

2. Chang, C-P., and Lee, C.-C. (2010). Globalization and Economic Growth: A Political Economy Analysis for OECD countries, Global Economic Review, Vol.39 (2), pp.151173.

3. Dima, S. (2016). Globalization, trade openness and foreign direct investment in Romania, Studia Universitatis"Vasile Goldiș" Arad, Economics Series, Vol. 26, Issue 4, pp.41-53.

4. Dreher, A.(2006). Does Globalization Affect Growth? Empirical Evidence from a new Index Globalization. Applied Economics, 38 (10), pp.1091-1110.

5. Dreher, A., Gaston, N., Martens, P. (2008). Measuring Globalization-Gauging its Consequence. New York: Springer.

6. Iovițu, M., Bodislav, A., Diaconu, A. (2015). Globalization-engine for economic growth. Journal of Knowledge Management, Economics and Information Technology Vol. V (6), pp.1-9.

7. Kilic, C. (2015). Effect of globalization on economic growth: a panel data analysis for developing countries. Economic Insights-Trends and Challenges, Vol.14, No.1, pp.111.

8. KOF, Index of Globalization. Available at http://globalization.kof.ethz.ch/ Accessed 10 June 2016.

9. Leitão, N.C. (2012). Economic Growth, Globalization and Trade. Management Research and Practice, Vol.4, Issue 3, pp.18-24.

10. Meraj.M. (2013). Impact of globalization and trade openness on economic growth in Bangladesh. Ritsumeikan Journal of Asia Pacific Studies, Volume 32, pp.40-50.

11. Morita, T., Takatsuka, H. and Yamamoto,K. (2015). Does globalization foster economic growth? The Japanese Economic Review Vol.66 (4), pp.492-519.

12. Mutascu, M. and Fleischer, A.-M. (2011). Economic Growth and Globalization in Romania. World Applied Sciences Journal, 12 (10), pp.1691-1697.

Studia Universitatis "Vasile Goldis" Arad. Economics Series Vol 27 Issue 1/2017

ISSN: 1584-2339; (online) ISSN: 2285 - 3065 
Neagu O., Dima S. (2017)

Impact of globalisation on economic growth in Romania: an empirical analysis of its economic, social and political dimensions

13. Neagu, O. (2014).How much does globalisation affect the income inequality in Romania? Studia Universitatis"Vasile Goldiş" Arad, Economics Series, Vol. 24, Issue 4, pp.76-83.

14. Polasek, W. and Sellner, R. (2011). Does Globalization Affect Regional Growth? Evidence for NUTS-2 Regions in EU-27.Economics Series 266, Institute for Advanced Studies. Available at: http://irihs.ihs.ac.at/2057/ accessed 4 June 2016.

15. Rao, B. B., Tamazian, A., Krishna, V.C. (2011). Growth effects of a comprehensive measure of globalization with country-specific time series data. Applied Economics, Vol.43 (5), pp.551-568.

16. Ray, S. (2012). Globalization and Economic Growth in India: A Granger Causality Approach. Journal of Law, Policy and Globalization, Vol. 2, 2012, pp.18-30.

17. Shaikh, F.M. and Shah, M.A. (2008). Impact of Globalization on Pakistan's Economy by Using CGE Model. International Conference on Applied Economics, pp.839-845.

18. Smith, J., Plummer, S. and Hughes M. (2017). Transnational social movements and changing organizational fields in the late twentieth and early twenty-first centuries. Global Networks 17 (1), pp.3-22.

19. Umaru, A. H., Ahmadu, A., Musa, S. (2013). Globalization and Its Impact on the Performance of the Nigerian Economy. Interdisciplinary Journal of Research in Business, Vol.2, Issue 8, pp.1-6.

20. Valli,V., Saccone,D. (2015).Structural Change, Globalisation and Economic Growth in China and India. The European Journal of Comparative Economics Vol.12 (2), pp.133163.

21. World Bank (WB) (2016), Data. Available at http://databank.worldbank.org/data Accessed 25-30 May 2016.

22. World Trade Organization (WTO), (2008). World Trade Report 2008 Trade in A Globalizing World, WorldTrade Report.

23.Zamfir, P.B.(2015). The influence of globalization on economic growth in Romania. Annals of the "Constantin Brâncuși" University of Târgu Jiu, Economy Series, Special Issue ECO-TREND 2015-Performance, Competitiveness, Creativity,pp.181-185.

24. Ying, Y.-H., Chang, K., Lee, C.-H.(2014). The Impact of Globalization on Economic Growth. Romanian Journal of Economic Forecasting, XVII (2), pp.25-34. 